\title{
特集「水循環基本計画の下での地下水に関する取り組み」の 揭載にあたって（その2）
}

\author{
竹内真司*

\section{Efforts related groundwater under the Basic Plan on Water Cycle Policy (Part 2 )}

\author{
Shinji TAKEUCHI
}

地下水は地中を循環する過程で人を含む生態系 に様々な恩恵を与えてきた。一方で高度経済成長 期の大量の地下水揚水や, 人口集中, 気候変動な どの様々な要因により地盤沈下や地下水の塩水 化，水質污濁などの問題が顕在化してきた。この ような状況下に拀いて, 地下水が人類共通の財産 であることを再認識し，地下水が健全に循環し， その恩恵を将来にわたって享受できるよう, 地下 水循環を維持, 又は回復するための施策を推進す ることが不可欠である（田中，2016）。

2014年 7 月 1 日に「水循環基本法」が施行され, 本法の制定をうけて，2015年 7 月10日には「水循 環基本計画」が閣議決定された。これらに基づい て国や自治体において様々な取り組みが行われて いる。このような背景の中, 日本地下水学会で は, 2016年12月 5 日に日本大学文理学部に扔い て, 水関連 8 団体の後援を得てシンポジウム「水 循環基本計画の下での地下水に関する取り組み」 を開催したことについては, 前号 (第59巻第 4 号) を参照していただきたい。

本特集は, 上記シンポジウムでの講演内容を, 各講演者らにまとめ直していただいた「論説」お よび「資料」から構成されている。これらのうち
本号では, 前号に続き, 研究者の立場から見た水 循環施策の現状と課題（田中氏）の論説を掲載す る。残り 3 編とパネルディスカッションの様子に ついては次号以降に揭載する予定である。

田中（2018）は, 地下水学の観点から「流域水 循環に果たす地下水の役割」「「地下水流動の可視 化」,「地下水ガバナンス」について述べ, 水循環 に関する施策の推進を図るための主な課題につい て記した。また，「持続可能な地下水の保全と利 用」に関する重要課題として, 個別法としての「地 下水保全法」の制定が必要不可欠であることを指 摘している。

日本地下水学会では,「水循環基本計画」の策 定（平成27年 7 月 10 日閣議決定）を受けた新たな WG の一つとして,「地下水ガバナンス等調査 . 研究グループ」を立ち上げ, 社会科学的な観点で の具体的な検討を開始したところである。

本学会拧よび関倸者諸氏が, 地下水の保全, 涵 養及び利用に関する取組に積極的に関わり，ま た，水循環基本計画に基づく活動を推進する上 で, 本特集の内容を役立てていただければ幸いで ある。

* 日本大学文理学部 - 企画委員会 $\cdot$ 編集委員会 
地下水学会誌 第 60 巻第 1 号 $15 \sim 16$ (2018)

\section{参考文献}

田中 正 (2018)：地下水学から見た水循環に関する施 策の推進を図るための現状と課題. 地下水学会誌,

田中 正（2016）：地下水保全法案の作成経過とシンポ ジウム総合討論のまとめ一地下水保全法のあるべき 60 (1), 17-28.

（受付：2017年12月18日，受理：2017年12月18日） 